\title{
IDENTIFIKASI TUJUAN DAN SASARAN PEMBANGUNAN DESA KABUPATEN ACEH BARAT
}

\author{
Nellis Mardhiah \\ Fakultas Ilmu Sosial dan Ilmu Politik Universitas Teuku Umar \\ nellismardhiah@utu.ac.id
}

\begin{abstract}
Research to identify goals and objectives for the development of rural areas implemented by local governments in Aceh Barat by law No. 6 of 2014 concerning Indonesian villages. Government Regulation No. 43 of 2014 on regulations implementing the law on the entire territory of Indonesia. The idea in the construction of the village area, to establish an independent village-based autonomy based on decentralization of policy goals of development planning top-down central government and development activities in bottom-up to the local government at the village level that is able to run continuously to carry out nation-building and livelihood both nations in the economic, political, social, cultural and defence security, and science and technology. The qualitative research method with descriptive approach to the phenomenon of primary and secondary data with the results of previous studies based on linkage with rural development. The theory of this study using the theory of decision-making and the development concept that has been implemented through the analysis of rural development top-down or bottom-up. Identify the goals and objectives of rural development is to create an autonomous rural development in a sustainable community economic empowerment.
\end{abstract}

Keywords: Identification, Goals, Objectives, Development, Village 


\section{PENDAHULUAN}

Pembangunan adalah aspek paling penting dalam suatu Negara yang pada hakikatnya untuk mewujudkan masyarakat yang sejahtera, demikian halnya Indonesia. Dalam Pembukaan Undang-Undang Dasar 1945 dinyatakan bahwa tujuan Pembangunan Nasional Bangsa Indonesia adalah melindungi segenap bangsa dan seluruh tumpah darah Indonesia, memajukan kesejahteraan umum, mencerdaskan kehidupan bangsa, serta ikut melaksanakan ketertiban dunia. Untuk mewujudkan tujuan tersebut dilaksanakan pembangunan nasional, yaitu pembangunan manusia Indonesia seutuhnya dan pembangunan masyarakat seluruhnya. Kesejahteraan ini akan dapat dicapai dengan mengurangi jumlah angka kemiskinan dan pengangguran.

Realisasi tujuan dan sasaran pembangunan, maka segenap potensi alam harus digali, dikembangkan, dan dimanfaatkan sebaik-baiknya. Begitu pula dengan Potensi manusia berupa penduduk yang banyak jumlahnya harus ditingkatkan pengetahuan dan keterampilannya sehingga, mampu menggali, mengembangkan dan memanfaatkan potensi alam secara maksimal, dan pelaksanaan program pembangunan tercapai.

Desa merupakan kesatuan masyarakat hukum yang memiliki batas wilayah yang berwenang untuk mengatur dan mengurus urusan pemerintahan, kepentingan masyarakat setempat berdasarkan prakarsa masyarakat. Mengenai peraturan pelaksanaan Undang-Undang Nomor 6 Tahun 2014 yaitu Penataan Desa, Kewenangan Desa, Pemerintahan Desa, Tata Cara Penyusunan Peraturan Desa, Keuangan dan Kekayaan Desa, Pembangunan Desa dan Pembangunan Kawasan Pedesaan, Badan Usaha Milik Desa, Kerjasama Desa, Lembaga Kemasyarakatan Desa, dan Lembaga Adat Desa dan Pembinaan dan Pengawasan Oleh Camat atau sebutan lainnya (PP No 43 Tahun 2014).

Desa merupakan wilayah yang memiliki hak otonom untuk mengatur dan meningkatkan pembangunannya sendiri. Seiring dengan perkembangan otonomi daerah, pemerintah pusat telah memberikan tugas perbantuan kepada pemerintah desa untuk selalu memperhatikan dan menekankan pembangunan masyarakat melalui otonomi pemerintahan desa serta peran aktif partisipasi masyarakat desa dalam pembangunan.

Desa berdasarkan penjelasan dalam Undang-Undang Nomor 6 Tahun 2014 dalam pasal 1 ayat 1 tentang desa adalah adat atau yang disebut dengan nama lain, selanjutnya disebut Desa. Desa adalah kesatuan masyarakat hukum yang memiliki batas wilayah yang berwenang untuk mengatur dan mengurus urusan pemerintahan, kepentingan masyarakat setempat berdasarkan hak asal usul, dan atau hak tradisional yang diakui dan dihormati dalam sistem pemerintahan Negara Kesatuan Republik Indonesia.

Kewenangan Desa meliputi kewenangan dibidang penyelenggaraan pemerintah desa, pelaksanaan pembangunan desa, pembinaan kemasyarakatan desa, dan pemberdayaan masyarakat desa berdasarkan prakarsa masyarakat, hak asal usul, dan adat istiadat Desa (UU No.6 Tahun 2014, Pasal 18).

Pelaksanaan dana desa dilakukan sesuai dengan Undang-Undang Nomor 6 Tahun 2014 Tentang Desa. Peraturan pemerintah nomor 43 tahun 2014 tentang peraturan pelaksanaan undang-undang nomr 6 tahun 2014 tentang desa. Peraturan pemerintah nomor 22 tahun 2015 tentang perubahan peraturan pemerintah nomor 60 tahun 2014 tentang dana desa yang bersumber dari pendapatan anggaran belanja negara, peraturan menteri keuangan negara nomor 93 tahun 2015 tentang pengalokasian, penyaluran, pemantauan dan evaluasi dana desa yang bersumber dari APBN, dan peraturan menteri desa pembangunan daerah tertinggal, dan transmigrasi nomor 5 tahun 2015 tentang penetapan prioritas penggunaan dana desa tahun 2015 .

Menindaklanjuti peraturan tersebut di atas maka pelaksanaan pembangunan desa dilaksanakan secara desentralisasi dalam perwujudan pembangunan desa melalui perencanaan pembangunan yang berbasis autonomi dalam rangka menciptakan kemandirian untuk meningkatkan pemberdayaaan masyarakat secara kesinambungan. Untuk itu, dalam rangka 
perwujudan pembangunan ini memerlukan sumberdaya yang handal dalam proses pengelolaan pembangunan tepat sasaran agar dapat dijalankan sesuai dengan aturan yang berlaku. Gagasan pembangunan ini telah diwujudakan diseluruh polosok Indonesia sejak tahun 2015/2016. Maka untuk itu dalam pelaksanaan pembangunan tersebut harus dapat diketahui tujuan dan sasaran pembangunan yang telah ditetapkan dalam undang-undang nomor 6 tahun 2014 tentang desa.

Alokasi pembangunan dana desa harus dapat diindentifukasikan sesuai dengan tujuan dan sasarn dalam pelaksanaan pembangunan. Maka berdasarkan acuan yang telah ditetapkan oleh pemerintah pusat secara pembangunan top-down iaitu basis pembangunan desa yang akan merencanakan dengan analisis bottom-up ketingkat pemerintah desa. Alokasi penggunaan dana desa yang berbasis otonomi tersebut adalah $70 \%$ digunakan untuk mendanai pelaksanaan pembangunan dan pemberdayaan masyarakat desa dan 30\% digunakan sebagai honorium dan operasional pemerintah desa. Maka setiap desa harus mampu memperhatikan persyaratan yang tercantum dalam undang-undang yang berlaku.

Undang-Undang Nomor 6 Tahun 2014 dijelaskan bahwa pembangunan desa bertujuan untuk meningkatkan kesejahteraan masyarakat desa dan kualitas hidup manusia serta penanggulangan kemiskinan melalui pemenuhan kebutuhan dasar, pembangunan sarana dan prasarana desa, pengembangan potensi ekonomi lokal serta pemanfaatan sumber daya alam dan lingkungan secara berkelanjutan. Dijelaskan pada bagian ketiga bahwa dalam pembangunan desa harus mengedepankan kebersamaan, kekeluargaan, dan kegotong royongan guna mewujudkan pengarustamaan perdamaian dan keadilan sosial.

Kedudukan Aceh sendiri merupakan salah satu provinsi dalam Negara Kesatuan Republik Indonesia mempunyai beberapa keistimewaan yang telah ditentukan dalam Undang-Undang Nomor 44 Tahun 1999 Tentang Tata Cara Pelaksanaan Keistimewaan Daerah, dan Gampong menjadi salah unsur dari keistimewaan itu sendiri. Namun pelaksanaan Pembangunan Gampong tentu merujuk pada perundang-undangan baik itu penganggaran dan pengelolaan dalam pembangunan Gampong. Dalam melaksanakan pembangunan tentunya diperlukan suatu pola menejerial dalam pengelolaan pembangunan, pola manejerial tersebut dimaksudkan agar setiap program pembangunan yang hasilnya akan dirasakan manfaatnya bagi masyarakat.

Alokasi dana desa di Aceh Barat tahun 2015 berjumlah 143 Milyar yang harus disesuaikan dengan perolehan dana desa yang bersumber dari aturan yang berlaku dalam proses penggunaannya dilihar berdasrkan kriteria iaitu, alokasi dana dasar, dibagi rata setiap desa sebesar 90\%, dan alokasi dengan memperhatikan jumlah penduduk, angka kemiskinan, luas wilayah serta ingkat kesulitan geografis setiap desa sebesar 10\%. Sejumlah dari alokasi tersebut di pemerintah daerah Aceh Barat secara dekonsentrasi pemerintah Aceh Barat telah mekasanakan tugas dan kewajipan dalam memberikan pendampingan secara horizontal muapun dengan secara vertikal dengan upaya dapat menwujudakan tujuan dan sasaran pembangunan yang telah diamanahkan dalam undang-undang yang berlaku.

Maka oleh karena itulah dalam artikel ini ingin membahas secara mendalam dari segi kedudukan undang-undang dapat dipahami analisis tujuan dan sasaran berdasarkan undangundang nomor 6 tahun 2014 tentang desa di wilayah Aceh Barat pada tahun 2015.

\section{KAJIAN LITERATUR}

Nilai sebuah kebijakan akan berjalan sesuai dengan yang diharapkan apabila didukung oleh berbagai faktor, salah satunya ketepatan pemilihan kebijakan atau keputusan sesuai dengan yang dibutuhkan publik, serta didorong oleh dukungan responsibilitas masyarakat yang partisipasi terhadap suatu kebijakan pemerintahan termasuk taat kepada hukum dan peraturan .

Namun sebuah Negara hukum tentunya tidak dapat begitu saja menjalankan fungsi sebenarnya dari hukum itu sendiri, diantaranya masih diperlukan kesadaran hukum dari setiap warganya, kesadaran tersebut tidak hanya sebatas kepatuhan, akan tetapi pemahaman secara mendalam terhadap tujuan suatu kebijakan yang merupakan intisari suatu keputusan, selain dari 
pada hal-hal lain yang berkaitan dengan kebijakan, seperti ketepatan pengambilan keputusan, serta implementasi yang baik dan benar, juga dengan dukungan dari berbagai elemen dan factorfaktor yang berpengaruh. Kebijakan pemerintah desa merupakan salah satu produk hukum karena setiap pemerintah desa secara hukum pun memiliki wewenang tersebut. Meskipun berskala kecil dan lokal yang menyangkut mencakup wilayah administrasi desa itu sendiri. Secara undang-undang kebijakan formal di level desa tertuang dalam bentuk peraturan desa. Secara struktur undang-undang dan ketatanegaraan, peraturan desa merupakan bentuk tindak lanjut serta penjabaran dari peraturan yang lebih tinggi, bukan untuk menjalankan otonomi secara independen, melainkan tanggung jawab otonomi desa tetap ada di bawah wewenang dan pengawasan pemerintah kota/kabupaten. Meskipun demikian desa memiliki hak dan wewenang berpartisipasi dalam menentukan arah pembangunan nasional secara umum serta pembangunan desa sendiri secara khusus. (Tachjan. 2006: 59).

Harnako (2008) dalam penelitiannya menunjukkan bahwa pembangunan dalam era otonoi daerah harus lebih proaktif partisipasi masyarakat demi terciptanya pembangunan yang secara partisipatif dalam mencapai tujuan dan sasarannya. Namun dalam pembangunan desa di era autonomi ini ke depan harus lebih terampil supaya pembangunan dapat menciptakan kemdirian bagi desa dalam menjalankan pembangunan.

Demikian pula penelitian Nurwanti (2008) menjelaskan bahwa Pemerintah desa dalam upaya pembangunan desa merupakan unsur pelaksana utama dalam melaksanakan perencanaan, menfasilitasi serta mendorong kewajipan kepada masyarakat secara partisipatif supaya mampu menciptakan pembangunan yang berinovasi dan kesinambungan dalam pelaksanaan pembangunan. Peranan pemeintah desa dalam pembangunan desa adalah memberdayakan kelembangaan desa yang pro aktif dalam meningkatkan partisipasi pembangunan desa yang keberlanjutan. Twikromo (2008) dalam penelitiannya menjelaskan bahawa pemerintah desa juga merupakan sebagai elit politik dalam melaksanakan pembangunan yang wajib dijalankan sesuai dengan amanah undang-undang yang berlaku dalam mneyukseskan pembangunan desa.

Purwaningsih (2008) dalam penelitiannya juga menjelaskan bahwa partisipasi masyarakat dalam pembangunan desa sebagai nilai yang sangat murni dalam menjalankan sistem pemerintahan yang model bottom-up playning sangat penting untuk berpartisipatif dalam menjalankan pembangunan. Menurutnya pelaksanaan pembangunan ini merupakan sebagai sebuah nilai kewujudan dalam mengindentifikasikan permasalahan pembangunan, potensi dan sesuai dengan wilayah nya dalam merencanakan pembangunan di tingkat desa untuk pemberdayaan masyarakat secara kesinambungan. Begitupula dalam penelitian Munawaroh (2008) pembangunan desa memerlukan partisipasi masyarakat buakan hanya dalam bentuk fisik namun nilai pendidikan dan pengetahuan, dan kondisi geografis keadaan desa juga mempengaruhi pelaksanaan pembangunan dan kerlibatan masyarakat. Maka oleh karena itu, peranan pemerintah desa sebagai elit dalam pembangunan desa harus menjadi perhatian pemerintah desa dalam memajukan desa secara kesinambungan harus menempatkan tugas hak dan kewajipan kepentingan masyarakat.

Mardhiah (2015) hasil penelitian menunjukkan bahwa pemerintah daerah pada umumnya telah memberikan pemahaman kepada aparatur ditingkat dalam perencanaan pembangunan yang partisipatif. Namun hasil penelitiannya menunjukkan bahwa kesiapan aparatur desa ini masih lemah dari segi sumberdaya manuasia dalam mengelola pelaksanaan pembangunan sebagai yang telah direncanakan. Begitu pula penelitian yang sama pada tahun 2016 yang telah dilakukan oleh beliau bahwa pembangunan desa harus lebih optimal kembali di tingkat pemerintah daerah dalam memberikan pemahaman tentang keberadaan tentang undang-undang supaya dapat mencipatakan pembangunan yang handal dalam aktualisasi diri pemerintah dalam inovasi mencipatakan pembangunan yang keberlanjutan yang telah direncanakan dalam RAPBG mahupun ketersediaan dalam APBG di tingkat desa. Demikian pula penelitian (Pakeh, 2016) tentang implementasi dana pembangunan gampong meruapakan nilai pembangunan 
masyarakat yang partisipatif dalam proses pembangunan baik perencanaan, penganggaran pembangunan yang dijalankan.

Berdasarkan hasil penelitian di atas menunjukkan pembangunan desa yang partisipatif merupakan sebuah nilai normatif yang harus diwujudkan dari peraturan yang berlaku untuk menciptakan pembangunan desa yang mandiri yang berbasisi autonomi melalui sistem bottomup yang partisipatif.

\section{Kebijakan Publik}

Kebijakan adalah aturan tertulis yang merupakan keputusan formal organisasi, yang bersifat mengikat, yang mengatur perilaku dengan tujuan untuk menciptakan tatanilai baru dalam masyarakat,. Kebijakan akan menjadi rujukan pertama para anggota organisasi atau anggota masyarakat dalam berperilaku.

Kebijakan publik merupakan modal utama yang dimiliki pemerintah untuk menata kehidupan masyarakat dalam berbagai aspek kehidupan. Dikatakan sebagai modal utama karena hanya melalui kebijakan publiklah pemerintah memiliki kekuatan dan kewenangan hukum untuk memanej masyarakat dan sekaligus memaksakan segala ketentuan yang telah ditetapkan. Walaupun memaksa, akan tetapi sah dan legitimate karena didasari regulasi yang jelas. Kalau di Indonesia bukan hanya sekedar Undang-Undang yang menjadi dasarnya, akan tetapi konstitusi Negara yang memberikan kewenangan itu sehingga kebijakan public memiliki kekuatan otoritatif. UUD 45 dalam pembukaannya mengatakan: "untuk melindungi segenap Bangsa Indonesia dan seluruh tumpah darah Indonesia maka dibentuk pemerintah Negara Indonesia". Dengan statetment ini maka jelas tugas pemerintah melalui kebijakan-kebijakan yang dibuatnya harusdapat melindungi dan memberi rasa aman kepada seluruh masyarakat dan tumpah darah Indonesia.

Sulaiman (1998 : 24 ): Kebijakan Publik itu adalah sebagai suatu proses yang mengandung berbagai pola aktifitas tertentu dan merupakan seperangkat keputusan yang bersangkutan dengan tindakan untuk mencapai tujuan dalam beberapa cara yang khusus. Dengan demikian maka konsep kebijakan public berhubungan dengan pola aktivitas pemerintahan mengenai sejumlah masalah serta mengandung tujuan.

Aminullah dalam Muhammadi ( 2001: 371-272 ): Untuk memahami kedudukan dan peran yang strategis dari pemerintahan sebagai public actor,terkait dengan kebijakan public maka diperlukan pemahaman bahwa untuk mengaktualisasinya diperlukan suatu kebijakan yang berorientasi kepada kepentingan rakyat.

Jadi dari penjelasan menurut para ahli diatas dapat kita simpulkan Kebijakan public adalah kebijakan-kebijakan yang dibuat oleh pemerintah sebagai pembuat kebijakan untuk mencapai tujuan tertentu dimasyarakat dimana penyusunannya melalui berbagai tahapan dan segala sesuatu sesuatu yang berkaitan dengan keputusan pemerintah, baik berupa program, peraturan dan lain-lain.

Menurut Thomas R. Dye (1995) dan James Anderson (2008) ada tiga alasan yang melatarbelakangi kebijakan publik adalah pertama; pertimbangan atau alasan ilmiah (scientific reasons). Kebijakan publik dipelajari dalam rangka untuk menambah pengetahuan yang lebih mendalam. Mulai asalnya, prosesnya, perkembangannya, serta akibat-akibat yang ditimbulkan bagi masyarakat (Anderson, James E. 2008).

Proses perumusan kebijakan menurut Freemen dan Sherwood yang mengembangkan model $\mathrm{C}$, yakni model proses pengembangan kebijakan (social-policy development process model) mengkemas proses pembuatan kebijakan ke dalam 3 tahapan adalah identifikasi, implementasi dan evaluasi. Proses perumusan dalam kebijakan ini dapat digambarkan dalam Gambar 1 seperti berikut: 


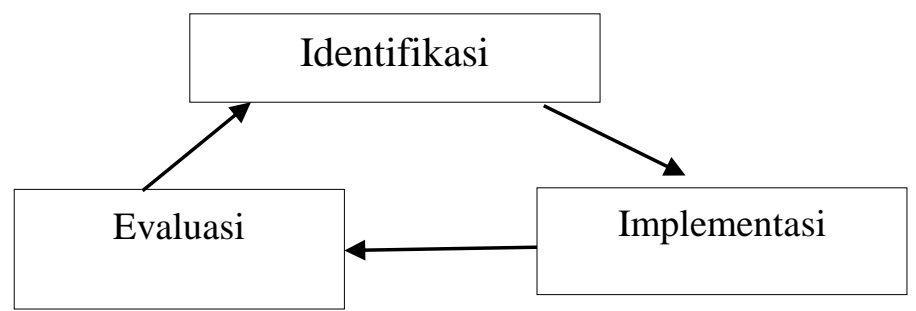

Gambar 2.1:

Model Segitiga Perumusan Kebijakan

\section{Tahap identifikasi}

Menurut Freemen dan Sherwood dalam buku (Suharto, 2010: 78) Identifikasi adalah masalah dan kebutuhan yang merupakan tahap pertama dalam perumusan kebijakan sosial adalah mengumpulkan data mengenai permasalahan sosial yang dialami masyarakat dan mengidentifikasi kebutuhan-kebutuhan masyarakat yang belum terpenuhi (unmet needs).

\section{Implementasi Kebijakan Publik}

Menurut Van Meter dan Van Horn (1975) dalam (Agustino, 2006: 138) Implementasi kebijakan merupakan suatu proses yang begitu kompleks bahkan tidak jarang bermuatan politis dengan adanya intervensi berbagai-bagai kepentingan. Serta tindakan yang dilakukan baik oleh individu-individu atau pejabat-pejabat atau kelompok-kelompok pemerintah atau swasta yang diarahkan peda terciptanya tujuan-tujuan yang telah digariskan dalam kebijaksanaan. Serta implementasi itu dianggap sederhana meski anggapan ini menyesatkan. Dengan kata lain, kelihatannya tidak mengandung isu-isu besar (Van Meter dan Van Horn, 1975: 450).

Problem implementasi diasumsikan sebagai sebuah deretan keputusan dan interaksi seharihari yang tidak terlalu perlu mendapatkan perhatian dari pada sarjana yang mempelajari politik. Implemetasi kebijakan yang dilakukan mengulaskan melalui pendekatan yang berbeda-beda untuk analisis tentang bagaimana kebijakan dilaksanakan dan dipraktikkan (Pearson, 2006: 463).

\section{Pembangunan top-down}

Pendekatan top-down ini memiliki pandangan tentang hubungan kebijakan implementasi seperti yang tercakup dalam implementasi kebijakan. Implementasi kebijakan adalah segala sesuatu yang baik diserahkan ke tangan sang pencipta. Segala sesuatu adalah buruk ditangan manusia. Model rasional ini berisi gagasan bahawa implementasi menjadikan orang melakukan apa-apa yang diperintahkan, dan mengontrol urutan tahapan dalam sebuah sistem; implementasi adalah soal pengembangan sebuah program kontrol yang menimbulkan konflik dan deviasi dari tujuan yang telah ditetapkan oleh hipotesis kebijakan (Pressman dan Wildavsky, 1973).

Gagasan dalam rasional melalui pendekatan implementasi Top-down juga seperti dalam pernyataan Max Weber dalam pernyataan (Dunsire, 1990: 26) gagasan rasionalitas tersebut hakikat birokrasi adalah kapan sesuatu tersebut berjalan dengan benar. Pemahaman tentang hakikat birokrasi adalah dari segi struktural, adalah fungsi spesialisasi yang sudah maju baik diranah horizontal mahupun vertikal. Implementasi kebijakan yang dilakukan merupakan proses pemikiran yang disebut sebagai "pelaksanaan" (opertionalising); dan penataan (organizing) "perekayasaan" atau "pendesainan" yang disebut dengan "pemprograman"(programming)".

\section{Pendekatan sistem rasional buttom-up}

Persoalan dalam kerangka buttom-up menekankan pada fakta bahwa implementasi memberikan keleluasaan dalam penerapan kebijakan. Para profesional punya peran yang penting dalam menjamin pelaksanaan sebuah kebijakan (Parsons, 2006: 471). 
Persoalan dalam pendekatan di atas membawa maksud adalah kerangka Top-Down dan Bottom-up bahwa kerangka itu cenderung menyederhanakan kompleksitas implementasi. Dua model awal yang memadukan dan mengembangkan pandangan dari kedua pendekatan tersebut adalah model yang dikembangkan oleh Lewis dan Flynn (1978). Lewis dan Flynn mengajukan sebuah model beheviorial yang memandang implementasi sebagai "tindakan" (action) dari individu yang dibatasi oleh dunia luar organisasi dan konteks institusional sebagai tindakan di lingkungan masyarakat. Seperti dalam Gambar 2 berikut ini tentang model Lewis dan Flyyn.

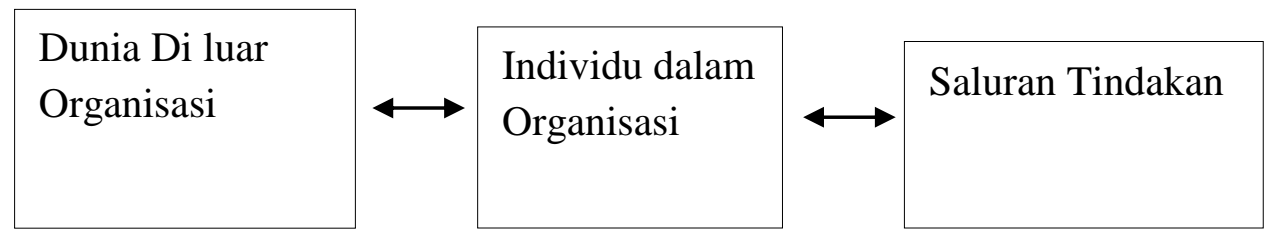

Sumber: Lewis \& Flynn (1978: 11)

Pelaksanaan kebijakan dalam kenyataannya ada ketidakpastian mengenai tujuan dan sasaran kebijakan; kekaburan dan ambiguitas tentang kebijakan dan ketidakpastian tentang pelaksanaannya; prosedur yang kompleks; inkonsistensi antara kekuasaan dan problem; dan konflik berasal dari partisipasi publik, aktivitas kelompok penekan dan perselisihan politik (Lewis dan Flynn, 1978: 5).

Interaksi dengan luar, konteks organisasi dan institusi, berarti pula bahawa tujuan kebijakan bukan sumber pedoman bagi tindakan. Oleh sebab itu sangat penting diketahui bahawa tindakan dari resolusi konflik antara dua prioritas dengan area kebijakan; mungkin mendahului formulasi prosedur untuk mengatasi kebijakan dengan kasus serupa dimasa depan; atau dengan apa yang dirasakan sesuai dengan situasi ketimbang pemenuhan tujuan aslinya (Lewis dan Flynn, 1978: 7).

\section{Evaluasi Kebijakan}

Menurut Michael scriven (1969)"Pengevaluasi harus mengevaluasi” merupakan penilaian itu sendiri tetapi sekaligus juga merupakan tautology. Karena itu lupakan anggapan bahwa evaluasi merupakan persoalan opini atau selera .Evaluasi merupakan persoalan fakta dan logika dan lebih penting dari yang paling penting (Dunn ,1992).

Evaluasi dalam artian singkat guna untuk melihat sejauhmana program kebijakan meraih dampak yang diinginkan. Perubahan kebijakan merupakan tahap selanjutnya setelah evaluasi setelah masalah-masalah timbul atau kegagalan-kegagalan kebijakan bisa diidentifikasi, sehingga ada siklus perubahan kebijakan.

Adapun fungsi evaluasi kebijakan memainkan sejumlah fungsi utama dalam menganalisis kebijakan. Pertama; evaluasi memberikan informasi yang valid dan dapat dipercaya mengenai kinerja kebijakan yaitu seberapa jauh kebutuhan, nilai dan kesempatan telah dapat di capai melalui tindakan publik. Maka dalam hal ini evaluasi mengungkapkan seberapa jauh tujuan lah tertentu dan target tertentu telah di capai. Kedua; evaluasi memberikan sumbangan pada klarifikasi dan kritik terhadap nilai-nilai yang mendasari pemilihan tujuan dan target. Ketiga; evaluasi member sumbangan pada aplikasi metode-metode analisis kebijakan lainnya termasuk perumusan masalah dan rekomendasi.

\section{Pembangunan Desa}

Pembangunan Desa merupakan bagian dari Pembangunan Nasional dan Pembangunan Desa ini memiliki arti dan peranan yang penting dalam mencapai tujuan nasional, karena desa 
beserta masyarakatnya merupakan basis dan ekonomi, politik, sosial budaya dan pertahanan keamanan.

Kartasasmita (2001:66) mengatakan bahwa hakekat pembangunan nasional adalah manusia itu sendiri yang merupakan titik pusat dari segala upaya pembangunan dan yang akan dibangun adalah kemampuan dan kekuatannya sebagai pelaksana dan yang akan dibangun adalah kemampuan dan kekuatannya sebagai pelaksana dan penggerak pembangunan. Pada hakekatnya pembangunan desa dilakukan oleh masyarakat bersama-sama pemerintah terutama dalam memberikan bimbingan, pengarahan, bantuan pembinaan, dan pengawasan agar dapat ditingkatkan kemampuan masyarakat dalam usaha menaikan taraf hidup dan kesejahteraannya.

Kebijakan Pembangunan perdesaan tahun 2010-2014 diarahkan untuk meningkatkan kesejahteraan dan kualitas hidup masyarakat perdesaan dengan langkah-langkah sebagai berikut: Pertama, Memperluas akses masyarakat terhadap sumber daya produktif untuk pengembangan usaha seperti lahan, prasarana sosial ekonomi, permodalan, informasi, teknologi dan inovasi, serta akses masyarakat ke pelayanan publik dan pasar; Kedua, Meningkatkan keberdayaan masyarakat perdesaan melalui peningkatan kualitasnya, dan penguatan kelembagaan serta modal sosial masyarakat perdesaan berupa jaringan kerjasama untuk memperkuat posisi tawar. Ketiga, Meningkatkan kesejahteraan masyarakat pedesaan dengan memenuhi hak-hak dasar; dan Keempat, Terciptanya lapangan kerja berkualitas dipedesaan, khususnya lapangan kerja non pemerintah.

Pembangunan Masyarakat Desa pada dasarnya adalah bertujuan untuk mencapai suatu keadaan pertumbuhan dan peningkatan untuk jangka panjang dan sifat peningkatan akan lebih bersifat kualitatif terhadap pola hidup warga masyarakat, yaitu pola yang dapat mempengaruhi perkembangan aspek mental(jiwa), fisik(raga), inteligensia (kecerdasan) dan kesadaran bermasyrakat dan bernegara. Akan tetapi pencapaian objektif dan target pembangunan desa pada dasarnya banyak ditentukan oleh mekanisme dan struktur yang dipakai sebagai Sistem Pembangunan Desa.

Pembangunan desa menurut Muhammad Zainul Abidin (2015) dalam penelitiannya yang berjudul "Tinjauan Atas Pelaksanaan Keuangan Desa Dalam Mendukung Kebijakan Dana Desa". Hasil penelitian menunjukkan bahwa Penggunaan ADD dilaksanakan dengan berpedoman pada Peraturan Pemerintah Nomor 72 Tahun 2005 tentang Desa dan disalurkan bagi pembangunan desa, pemberdayaan masyarakat, dan peningkatan pendapatan sehingga berhasil meningkatkan kesejahteraan masyarakat desa. Namun, sejumlah hasil penelitian yang telah diangkat dalam kajian tersebut telah mengungkapkan bahwa penggunaan ADD masih menemui sejumlah hambatan/permasalahan dalam perencanaan, pelaksanaan, kualitas pelaporan, dan lemahnya kelembagaan desa serta koordinasi dengan Pemerintah Daerah Kotamadya/Kabupaten.

Begitu pula penyataan Muhammad Hasbi (2015) bahwa penggunaan dana gampong evaluasi dana gampong Alue Lhee berdasarkan program-program yang telah dilakukan selama 5 (lima) tahun yang dana diambil dari dan ADG (Alokasi Dana Gampong) telah terlaksana dengan baik. Keadaan demikian menunjukkan bahwa manajerial pemerintah Gampong tepat sasaran dalam pelaksanaan pembangunan di sesuaikan dengan target pembangunan yang telah ditetapkan sebelumnya. Maka oleh karena itu, pembangunan dapat berjalan secara kesinambungan.

\section{METODOLOGI PENELITIAN}

Lokasi penelitian ini akan dilaksanakan di Kabupaten Aceh Barat Provinsi Aceh. Aceh barat terdiri dari 12 kecamatan dan 322 desa.Penelitian ini menggunakan data primer dan sekunder. Data primer adalah hasil wawancara secara mendalam dan langsung informan kunci yang berkaitan dengan Bupati, Bappeda, Kepala Desa dan Tuha Peut yang terwakili dari beberapa wilayah Kecamatan. Pengumpulan data primer 
dengan menggunakan instrumen penelitian, yaitu interview guide dan wawancara tak tersruktur".

Metode pengambilan data dilakukan dengan wawancara mendalam (indept interview) dan hasil FGD Moleong (2011, h. 186) mengatakan bahwa wawancara adalah percakapan dengan maksud tertentu, di mana percakapan itu dilakukan oleh pewawancara (interviewer) atau yang mengajukan pertanyaan dan yang diwawancarai (inteveiweer). Penentuan informan menggunakan snowball sampling di mana penentuan informan dari jumlah yang terkecil sampai pada jumlah yang terbesar sehingga mencapai data jenuh (Sugiyono, 2005, h. 53-54).

Instrumen utama dalam penelitian ini adalah sederhana, diharapkan dapat melengkapi data dan membandingkan dengan data yang telah ditemukan melalui observasi dan wawancara, peneliti akan terjun kelapangan sendiri, baik pada grand tour question, tahap focused and selection, melakukan pengumpulan data, analisis dan membuat kesimpulan (Sugiono, 2013 : 307). Secara umumnya analisis bersifat kompleks dari segi pelaksanaannya yaitu untuk mengorganisisr data hasil wawancara dengan informan di lapangan.

\section{HASIL PENELITIAN DAN PEMBAHASAN \\ Identifikasi Tujuan dan Sasaran Pembangunan Desa}

Pelaksanaan pembangunan desa yang dilaksanakan di Kabupaten Aceh Barat melaui tahapan awal adalah Pelaksanaan Sosialisasi undang-undang nomor 6 tahun 2014 tentang desa. Pelaksanaan undang-undang tersebut telah dituangkan dalam bentuk peraturan Bupati Aceh barat.

Pelaksanaan sosialisasi dengan tujuan dalam rangka menyukseskan dana desa di Kabupaten Aceh Barat. Dalam rangka menyukseskan pelaksanaan kegiatan ini Bupati dan Bappeda dan seluruh stakeholders menyukseskan dalam tahapan pelaksanaan sosialisasi undang-undang ini dengan tujuan dapat melaksanakan pembangunan desa yang mandiri yang berbasis autonomi. Pelaksanaan sosialisasi tahap awal tentang peraturan pengalokasian dana desa dan rancangan peraturan Bupati tentang dana desa. Pelaksanaan sosialisasi tentang dana desa ini di Kabupaten Aceh Barat pada tanggal 19 -27 Januari 2015 di seluruh wilayah Kecamatan di Kabupaten Aceh Barat. Pelaksanaan kegiatan ini adalah kegiatan lokakarya di Kantor Bappeda di Kabupaten Aceh Barat mengenai keberadaan informasi dana desa. Peserta dalam pelaksanaan dana desa ini adalah Keucik dan Tuha Peut serta tokoh masyarakat dan para kaur pembangunan yang ikut serta sebagai partisipan dalam pelaksanaan sosialisasi dana desa.

Identifikasi dana desa merupakan langkah yang dimaksud oleh pemerintah daerah untuk memberikan pemahaman kepada aparatur desa di wilayah kecamatan adalah harus mengetahui permasalahan pembangunan di pemerintahan desa baik pembangunan fisik mahupun non fisik dengan harapan dapat diwujudkan dan diselaraskan dalam pelaksanaan pembangunan melalui dana desa.

Selanjutnya kegiatan sosialisasi ini dengan melakukan pelatihan lebih mendalam kepada para peserta dari unsur kecamatan dilaksanakan pada tanggal 5 febuari 2015 di aula Bappeda Kabupaten Aceh Barat. Kegiatan ini yang dimaksud oleh pemerintah Aceh Barat adalah para aparatur wilayah Kecamatan dapat membimbing aparatur desa dalam penyusunan perencanaan pembangunan iaitu RPJMG (Rancangan Pembangunan Jangka Menengah Gampong), RKPG (Rancangan Keuangan Pembangunan Gampong) dan APBG (Anggaran Pendapatan Belanja Gampong) sekali gus dalam gagasan ini dilakukan oleh pemerintah Aceh Barat sebagai tim verifikator dokumen dalam perencanaan pembangunan gampong. Maka untuk itu, pemerintah wilayah kecamatan harus secara akuntabel dapat menyelaraskan perencanaan pembangunan dengan aparatur desa di wilayah kecamatan dengan harapan pembangunan dapat berjalan secara kesinambungan sesuai dengan peraturan yang berlaku. 


\section{Sasaran Pembangunan Desa}

Jenis kegiatan pelaksanaan pembangunan desa dilakukan melalui hasil MUSRENBANGDES yang telah ditetapkan. kemudian hasil dari pelaksanaan musyawarah tersebut Keucik sebagai kepala desa sebagai lembaga eksekutif dan Tuha Peut atau lembaga legislatif melaksanakan sasaran pembangunan sesuai dengan aturan yang berlaku. Sasaran pembangunan sesuai dengan aturan yang ada tidak dibenarkan untuk pembangunan rumah ibadah. Rumah ibadah merupakan sebuah hasil dari swadaya masyarakat.

Sasaran pembangunan yang lain nya adalah rehabilitasi infrastruktur sarana dan prasarana pemerintahan desa, atau pun pengadaan yang baru dalam saranan ini. Namun, dalam pengelolaan dana desa ini lebih diarahkan dalam pemberdayaan perekonomian masyarakat, sosial budaya sei dan olahraga, pelatihan barang dan jasa ke masyarakat, penanggulangan bencana, penanggulangan sampah, saluran irigasi persawahan.

\section{Pelaksanaan Pembangunan Desa}

Pelaksanaan pembangunan desa dilaksanakan oleh masyarakat secara partisipatif, dengan kata lain pelaksanaan pembangunan yang berdasarkan dana desa tahun 2015-2016 berdsarkan hasil data dilapangan adalah hasil dari swadaya masyarakat. Begitu pula sistem pelaksanaan dalam pengadaan barang dan jasa sesuai dengan Peraturan Bupati Nomor 5 Tahun 2015 tentang pengadaan barang dan jasa oleh TPK (Tim Pengelola Kegiatan) yang berjumlah 5 yang terdidiri dari ketua, sekretaris, anggota 3 orang dengan melibatkan masyarakat yang berpotensi dan peduli terhadap perencanaan dan pengembangan pembangunan di desa. Peran yang dimaksud tokoh pemuda dan tokoh perempuan.

Tokoh perempuan dalam pembangunan sangat mempengaruhi kedudukannya. Hal ini disebabkan keberadaan perampuan merupakan upaya perkembangan dalam lingkungan hidup dalam kehidupan sehari-hari. Maka oleh karena itu, perempuan dalam pembangunan dapat dijadikan sebagai gagasan pembangunan bangsa secara aspiratif. Persyaratan khusus menjadi tim pelaksana kegiatan adalah unsur perempuan, Keucik, Sekdes dan Bendahara. Sedangkan Tuha Peut tidak termasuk anggota TPK. Pelaksanaan pembangunan desa dalam PERBUP tersebut telah dijelaskan bahwa pelaksanaan swakelola yag dilaksanakan oleh TPK melalui tahap kegiatan persiapan, pelaksanaan, pengawasan, penyerahan hasil dan pertanggungjawaban hasil pekerjaan. Namun bagi pekasanaan hasil kegiatan dengan memakai sarana yang diperlukan seperti peralatan berat tidak dapat diswadaya sendiri oleh TPK. Hal ini TPK dapat melaksanakan penyediaan barang dan jasa oleh pihak lain yang mampu di anggap oleh TPK.

Pelaksanaan pembangunan desa juga melibatkan stakeholders aparatur desa dan Tuha Peut agar dapat mengelola dan tersebut dengan baik. Kemudian Keucik sebagai kepala desa dapat membina aparatur dibawahnya sesuai dengan manajemen kepemimpinan menjalin komunikasi yang baik dengan mengutamakan tim dalam menyukseskan pelaksanaan pembangunan desa. Dana desa yang dimaksud untuk menumbuhkan syair islam di peringkat desa sebagai yang telah diamanahkan dalam peraturan yang berlaku.

\section{SIMPULAN}

Identifikasi sasaran pembangunan desa diwilayah Aceh Barat dapat diketahui bahwa telah dilakukan melalui sosialisasi tentang sasarn pembangunan dan tujuan pembangunan sesuai dengan peraturan yang berlaku.

Begitupula sasaran pembangunan terlebih dahulu yang harus menjadikan pusat perhatian adalah infrastruktur desa terutama kantor atau balai desa sebagai sasaran dan sarana dalam memberikan pelayanan publik yang lebih efektif dan efisien.

Pelaksanaan pembangunan desa dari sejumlah wilayah Aceh Barat belum dapat diidentifkasikan dengan jelas memerlukan waktu penelitian lanjutan tentang pelaksanaan dan pengelolaan pembangunan desa. Maka untuk itu, dalam pelaksanaan pembangunan desa sudah 
direalisasikan sesuai dengan aturan yang berlaku melalui proses sosialisasi yang telah dilakukan oleh pemerintah daerah Aceh Barat.

Unsur pembangunan dan dari perencanaan dan pelaksanaan pembangunan merupakan hasil dari swadaya masyarakat sendiri dalam perencanaan pembangunan terutama pembangunan ekonomi yang dirahkan sebagai pemberdayaan masyarakat sebagai inovasi pembangunan desa yang keberlanjutan. Namun dalam swadaya pembangunan ini dalam aspek pembangunan sosial budaya adalah infrastruktur pembangunan ibadah merupakan swadaya masyarakat sendiri dalam pembangunan.

\section{Ucapan Terima Kasih}

Ucapan Terimakasih penulis mengucapkan kepada Allah SWT telah memberikan kesempatan waktu kepada penulis untuk melaksanakan penelitian ini. Penulis juga mengucapkan terimakasih kepada Dekan Fakultas Ilmu Sosial dan Ilmu Politik yang telah menyetujui perencanaan penelitian ini dilakukan di lokasi penelitian selama tahun bulan mei tahun 2015 dan siap pelaksanaan akhir tahun 2016. Dan kepada pihak LPPM yang telah memberikan rekomendasi dalam pelaksanaan penelitian ini di Kabupaten Aceh Barat.

Kemudian penghargaan yang sepihak Bappeda Aceh Barat yang telah menluangkan waktu dan memberikan data dan informasi mengenai pelaksanaan pembangunan gampong di wilayah Aceh Barat.

Begitu juga kepada rekan-rekan teman sejawat yang telah membantu memberikan dokumen dan data informasi yang berkenaan tentang penelitian ini selama berlangsung.

Demikian penulis sampaikan dalam kekeliruan dalam tulisan ini penulis memohon maaf semoga data informasi yang telah disajikan dalam tulisan ini dapat dijadikan sebagai inspirasi dan sumber referensi bagi penulis tentang pembangunan desa yang lain di seluruh wilayah Indonesia.

\section{REFERENSI}

Anderson,J.E. (2008). Public Policy Making (Eigtht.,p. 125). New York: Praeger.

Dunn, W.N. (1992). Analisis Kebijakan Publik (Edisi., Ke-2., p. 22). Gajah Mada: University Press

Harnoko.D., (2008) Pembangunan di Tingkat Lokal dalam Autonomi Daerah, Jurnal Sejarah Budaya. Vol. III. No. 6. p. 391

Lewis, J. and R. Flynn. (1978), The Implementation Of Urban and Regional Planning Policies. London: Final Report Of A Eassibility Study For Departement of the Environment.

Lindblom, C. (1968). The Policy Making Process. Prentice-Hall. Englewood Cliffs, N.J. Nauendorf, K.A. (2012). The Content Analysis Guidebook. Sage: Publication Limited. 2012

Nurwanti. Y.H. (2008). Pemerintah Desa Dalam Upaya Pembangunan Desa. Jurnal Sosial Budaya. Vol. III. No. 6. p. 398

Mardhiah. N, \& M.N. (2016). Kesiapan Pemerintah Darah Dalam Memberikan Pemahaman Kepada Aparatur Gampong Tentang Undang-Undang Desa. Prosiding Nasional IAPA. p.105

Munawaroh. (2008). Partisipasi Masyarakat Dalam Pembangunan Desa. Jurnal Sosial Budaya. Vol. III. No. 6. p.453

Pakeh. A. (2016). Impelementasi Kebijakan Dana Gampong. Jurnal Public Policy. Vol. II. No. I p. 23 
Purwaningsih E. (2008) Partisipasi Masyarakat Dalam Pembangunan Desa. Jrnal Sosial Budaya. Vol.III. No. 6. p.443

Pearson,W. (2006). Public Policy. University Kingdom. London

Pressman, J. and A. Wildavsky. (1973). Implementation. University California Press. Barkeley

Suharto, E. (2012). Analisis Kebijakan Publik. Bandung : Alfabeta

Sulaiaman. A. (2008). Perumusan Kebijakan dan Koordinasi Pembangunan Indonesia, Bina Aksara. Jakarta

Sugiyono. (2005). Memahami Penelitian Kualitatif. Alfabeta. Bandung

Strauss, A.L. (1987). Qualitative Analysis For Social Scientist. Press Sydicate University Cambridge. New York

Twikromo. Y.A, (2008). elit Lokal Dalam Pembangunan Desa. Jurnal Sejarah Budaya. Vol. III. No, 6. p.407

Tachjan. (2006). Impementasi Kebijakan Publik. AIPI. Bandung.

Van Meter at. all. (1975). The Policy Implementation Process: A Conceptual Framwork. Administration at Society

Winarno, B. (2007). Kebijakan Publik Teori dan Proses. Media Pressindo. Jakarta

\section{Dokumen:}

Undang-Undang Dasar 1945

Undang-undang Nomor 44 Tahun 1999 Tentang Penyelenggaraan Keistimewaan Aceh

Undang-Undang Nomor 6 Tahun 2014 Tentang Desa

PP Nomor 43 Tahun 2014 Tentang Pelaksanaan Undang-Undang Desa 